\title{
Adaptive model predictions of daily total column ozone over the Amazon Inter-Tropical Confluence Zone
}

\author{
Julio Cesár González-Navarrete ${ }^{1, *}$, Julian Salamanca ${ }^{2, * *}$
}

\author{
Edited by \\ Juan Carlos Salcedo-Reyes \\ (salcedo.juan@javeriana.edu.co) \\ 1. Departamento de Física, \\ Universidad Nacional de Colombia, \\ Bogotá, Colombia. \\ 2. Grupo de Física e Informática, \\ Facultad de Ciencias y Educación, \\ Universidad Distrital Francisco \\ José de Caldas, Bogotá, Colombia. \\ *jcgonzalezna@unal.edu.co \\ ** jasalamanca@udistrital.edu.co \\ Received: 08-10-2018 \\ Accepted: 12-07-2019 \\ Published on line: 15-10-2019 \\ Citation: González-Navarrete JC, \\ Salamanca J. Adaptive model \\ predictions of daily total column \\ ozone over the Amazon \\ Inter-Tropical Confluence Zone, \\ Universitas Scientiarum, 24 (3): 425-439, 2019. \\ doi: 10.11144/Javeriana.SC24-3.ampo \\ Funding: \\ N.A.
}

Electronic supplementary material: N.A.

OPEN ACCESS

\begin{abstract}
The aim of this paper is to broaden the scope of a recent adaptive model in order to obtain predictions of total column ozone (TCO) trends over the Amazon Inter-Tropical Confluence Zone (ITCZ). The adaptive model makes daily TCO predictions over the tropical equator-Andes-Region, relying on seasonal patterns and the solar cycle. This study uses daily observations of the sunspot number cycle, given by the World Data Center for the production, preservation and dissemination of the international sunspot number (Royal Observatory of Belgium), and satellite total-column ozone data, collected by NASA (January 1979 to April 2018), for two Colombian locations: one in and one adjacent to the ITCZ. The agreement between daily total-column predictions by the adaptive model and satellite observations is excellent. Daily averaged relative errors around of $3.7 \%$ and $2.8 \%$ for both locations are reported herein.
\end{abstract}

Keywords: inter-tropical confluence zone; solar radiation; sunspot number; total column ozone.

\section{Introduction}

In the second half of the $20^{\text {th }}$ century, several studies looked for a possible relationship between the variations of the total column ozone (TCO) and the cycles of solar activity (e.g., Willett 1962, Keating et al. 1981, Angell 1989, Labitzke \& Van Loon 1997, Zerefos 1997, Haigh et al. 2010, Miyagawa et al. 2014) with no success in establishing such an acceptable statistical relationship.

Attempts to produce phenomenological models that describe the effects of solar activity on the ozone layer did not show a specific dependency with respect to a geoposition on Earth and to the day of the year (Soukharev \& Hood 2006, Randel $\&$ Wu 2007). Moreover, approximations to show the effect of solar activity, not 
for stratospheric but for tropospherical ozone, have been proposed, e.g., Selvaraj et al. (2010) achieve a 0.88 pearson correlation coefficient between tropospheric ozone and solar activity for a tropical rural coastal site in India. That study used annual averages for 9 years of data. Other studies report the combined influence of the solar activity and terrestrial effects (e.g., Quasi-Biennial Oscillation) on the stratospheric ozone (Kuttippurath \& Nair 2017, Roscoe \& Haigh 2007).

Based on the foregoing, and the need for a model to predict the evolution of the ozone layer (Stolarski \& Frith 2006) since a vast set of data taken by different satellite missions have been available from 1978, the aim of this paper is to extend the use of an adaptive model to study the behavior and make daily predictions of TCO over the Inter-Tropical Confluence Zone (ITCZ). The adaptive model (Gonzalez-Navarrete \& Salamanca 2018) is build upon a direct relationship between TCO and the solar activity by means of the sunspot number, which reports daily predictions of TCO over the equator-Andes-Colombian region.

In order to analyze the behavior of the ozone layer over the ITCZ, a data set of 39 years of National Aeronautics ans Space Administration (NASA) observational satellite data are taken into account (McPeters 2018). In this study, the ITCZ region is characterized by two locations: Leticia, the southern city of Colombia, which is located very deep in the Amazon Region and lies inside the ITCZ all the year long; and Riohacha, the northernmost city of Colombia, found adjacent to the ITCZ from November to July, and inside of it from August to October.

\section{TCO satellite data}

TCO measurements over Leticia $(4.09 \mathrm{~S}, 69.57 \mathrm{~W})$ and Riohacha $(11.32 \mathrm{~N}$, $72.56 \mathrm{~W})$ were given by NASA satellite missions Nimbus-7, Earth-Probe, Aura (Latin for breeze), and Russian satellite mission Meteor-3. Table 1 lists satellite mission data sets for this study, with comments on the instrumentation used to obtain observational data and its continuity.

Satellite data were chosen by studying the missions' timing overlap, when one mission comes to the end and the other one starts its operation. For example, Aura mission started its operations on July 2004 and Earth Probe ended in 2005-2006; for consistency, data for 2004 was taken from Earth-Probe, and for 2005 from Aura.

As a result of a change in on-board satellite instrumentation for measuring TCO, available data sets from NASA have two different geopositional resolutions. While Nimbus-7, Meteor-3 and Earth-Probe data have a resolution of 1.25 degrees in longitude and 1.0 degrees in latitude (Text format), Aura data resolution (HDF format) have 0.25 degrees for both, longitude and latitude. Grid resolutions were consistently taken into account in this study.

Fig. 1 and Fig 2 show the historical TCO data for Leticia and Riohacha from 1979 to 2018 . 


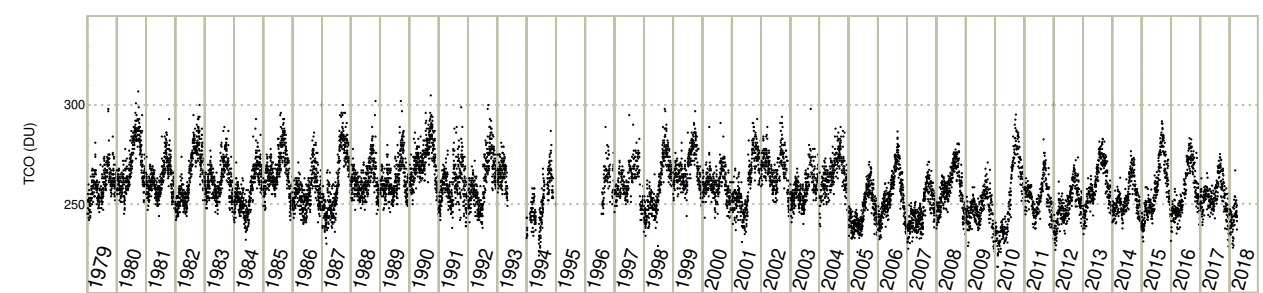

Figure 1. Daily TCO satellite data for Leticia (in Dobson Units, DU) from 1979 to 2018. Satellite-instrument source: TOMS, OMI.

For both locations, a cyclic seasonal behavior is found. It exhibits a minimum value of total ozone around January, rises up to the maximum in September and finally decreases until December.

\section{The adaptive TCO predicting model}

The model has three specific aspects: seasonal patterns, behavior of solar radiation and the interactions between ultraviolet solar radiation and TCO. Its functional form is written as:

$$
O_{3}(n, m, Y Y, T)=A\left[S_{n}(n)\right] G\left[I_{\text {sei }}, n\right] F(m, Y Y-T),
$$

where $A\left[S_{n}(n)\right]$ accounts for part of the seasonal patterns and TCOultraviolet-radiation interactions regarding the sunspot number $S_{n}, G\left[I_{\text {sei }}, n\right]$ describes fractional variations between daily solar extraterrestrial radiation at location $\left(I_{\text {sei }}\right)$ relative to the solar constant $\left(I_{\text {sc }}\right)$, and $F(m, Y Y-T)$ is an empirical function that takes into account all physical ultraviolet radiation-matter interaction processes of stratospheric ozone entangled in data (Gonzalez-Navarrete \& Salamanca 2018).

It should be noted that the model depends on the day $n$ of the year, the year $Y Y$ for which the daily prediction of TCO will be made, the month $m$ of the year, and the solar cycle period of daily sunspot number $T$. This sunspot cycle period corresponds to 11 years with an uncertainty of \pm 14 months as reported by Hathaway (2010). Fig. 3 clearly shows the cyclic behavior of sunspot number observations as a function of $n$ since 1818 .

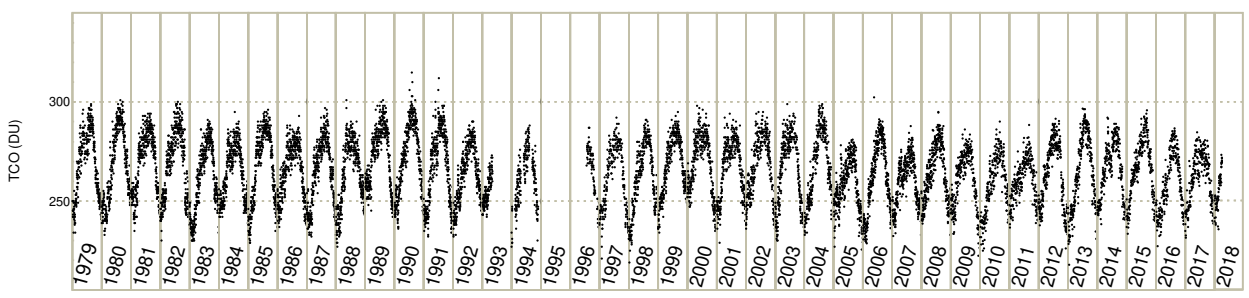

Figure 2. Daily TCO satellite data for Riohacha (in Dobson Units, DU) from 1979 to 2018. Satellite-instrument source: TOMS, OMI. 
Table 1. Satellite mission data sets by year, from 1979 to 2018. At present, quality of TCO-NASA data is enhanced by Version-8 algorithm, which accounts for time and geopositional corrections by reflectivity over TOMS diffuser plate (Total Ozone Mapping Spectrometer), refinement of correction algorithms for data-homogenization, systematic errors between TOMS and SBUV/OMI (Solar Backscatter Ultra Violet/Ozone Mapping Instrument), extreme conditions as dust, solar reflection from ocean and ice and wide zenith angle corrections, among other improvements (Wellemeyer et al. 2004).

Time Window Satellite Mission Comments

\begin{tabular}{lcl}
\hline 1979-1993 & Nimbus-7 & $\begin{array}{l}\text { Only } 30 \% \text { annual data reported for } 1993 . \\
\text { Instrumentation: TOMS. }\end{array}$ \\
1994-1995 & Eeteor-3 & $\begin{array}{l}\text { No data reported for 1995. 30\% of annual data reported } \\
\text { for 1994. Instrumentation: TOMS. }\end{array}$ \\
$1996-2004$ & Aura & $\begin{array}{l}\text { Only 30\% of annual data reported for } 1996 . \\
\text { Instrumentation: TOMS. }\end{array}$ \\
2005-2018 & Instrumentation: OMI. & \\
\hline
\end{tabular}

The adaptive model only takes sunspot data from 1979 to 2018.

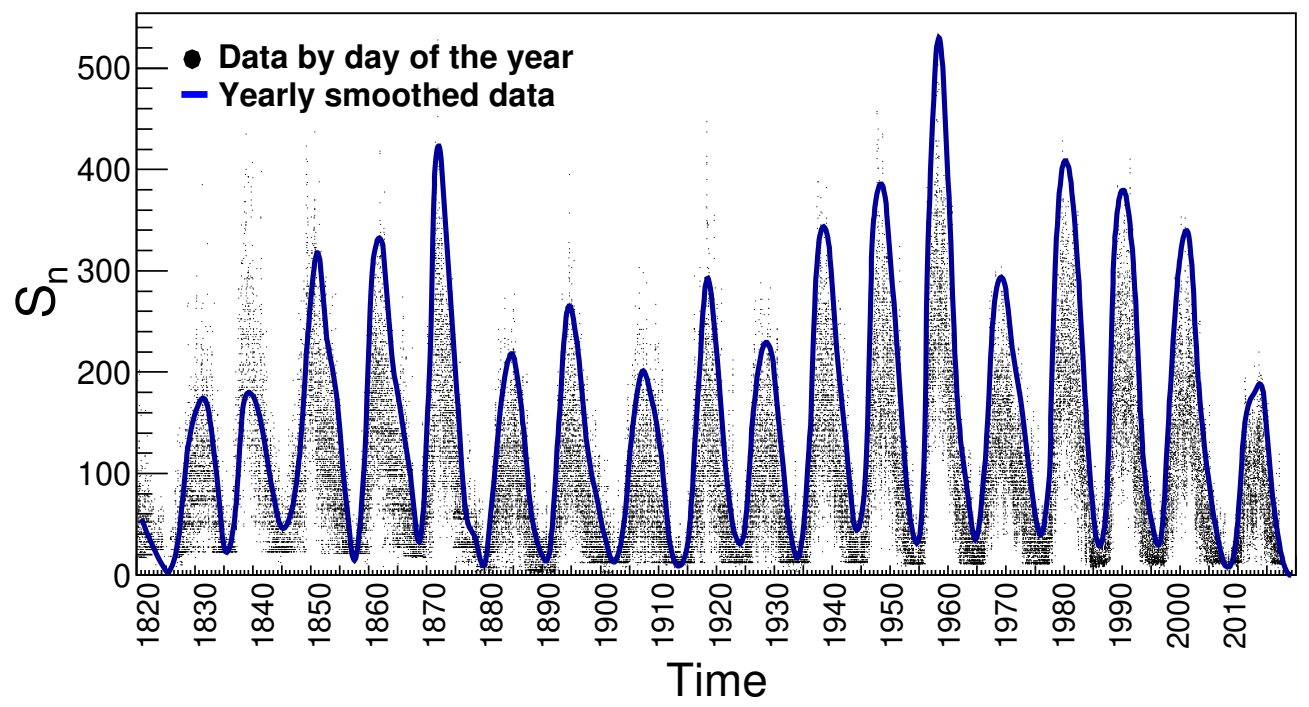

Figure 3. Daily sunspot number from 1818 to 2018. Data records are given by the World Data Center for the production, preservation and dissemination of the international sunspot (SILSO 2018). 
$A\left[S_{n}(n)\right]:$ TCO averages as a function of sunspot number $\left(S_{n}\right)$

The adaptive model proposes a relationship between TCO satellite measurements for a specific location on Earth, $O_{3, \text { sat }}(n)$, and $S_{n}(n)$ reported observations, both functions of $n$.

Time parametric equations regarding TCO and $S_{n}$ measurements allow the model to describe a $O_{3, \text { sat }}(n)-S_{n}(n)$ phase space for 39 years of historical data, from 1979 to 2018. Fig. 4 (left panel) shows a well defined pattern followed by the phase space that suggests a functional relationship between $O_{3, \text { sat }}$ and $S_{n}$.

As it can be seen, there is a corresponding set of $O_{3, \text { sat }}$ measurements for each integer value of $S_{n}$. By computing $O_{3 \text {,sat }}$ averages for a single $S_{n}$, which are named as $A\left[S_{n}(n)\right]$ in the model, Figure 4 (right panel) reveals a well-defined linear relationship between $A\left[S_{n}(n)\right]$ and $S_{n}(n)$ for Leticia and Riohacha. These results are consistent with a well-defined linear relationship discovered by the adaptive model for the city of Bogota (Gonzalez-Navarrete \& Salamanca 2018).

From fitting results, the $\chi^{2} / \mathrm{ndf}$ statistical test values of 1.32 and $1.31\left(\chi^{2} / \mathrm{ndf}\right.$, chi-squared test divided by number of degrees of freedom, ndf), respectively for Leticia (LET) and Riohacha (RCH), allows a functional linear relation between $A\left(S_{n}\right)$ and $S_{n}$ to be established as:

$$
\begin{aligned}
& A_{\mathrm{LET}}\left[S_{n}(n)\right]=255.5+0.036 S_{n}(n), \\
& A_{\mathrm{RCH}}\left[S_{n}(n)\right]=261.8+0.032 S_{n}(n),
\end{aligned}
$$
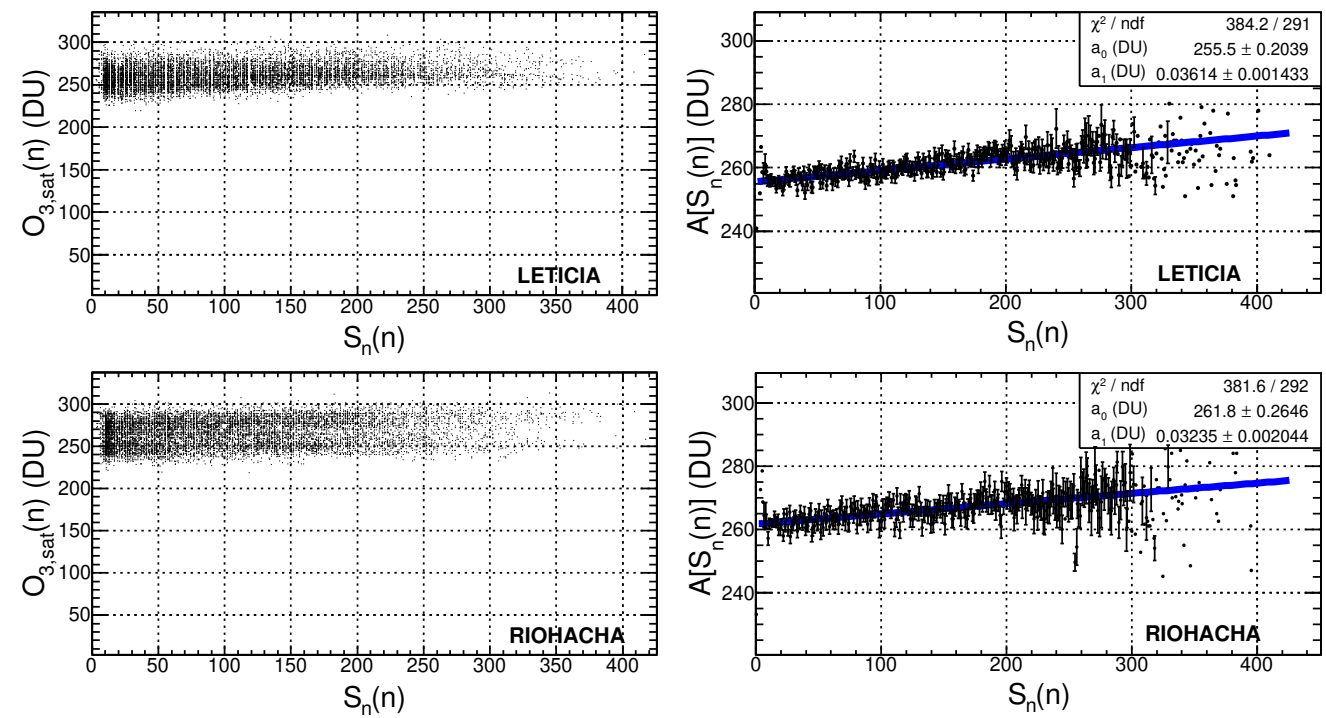

Figure 4. Linear relationship between TCO and sunspot observations for Leticia and Riohacha. Left panel: $O_{3, \text { sat }}(n)$ versus $S_{n}(n)$. Right panel: $A\left[S_{n}(n)\right]-S_{n}(n)$ phase space fitting results. 
where $A\left[S_{n}(n)\right]$ is expressed in Dobson Units (DU) and the slope can be understood as a change of TCO averages per unit of sunspot number.

$G\left(I_{\text {sei }}, n\right)$ : Fractional extraterrestrial solar radiation.

Extraterrestrial solar irradiance at location is directly related to the solar activity. It can be delineated by a fractional variation of daily extraterrestrial radiation at any location on Earth, $I_{\text {sei }}$, relative to the solar constant, $I_{\mathrm{sc}}$, weighted by the cosine of the solar zenith angle, $z$.

Since $z$ is a function of the day $n$ of the year, $G\left(I_{\text {sei }}, n\right)$ is expressed as (Gonzalez-Navarrete \& Salamanca 2018):

$$
G\left(I_{\text {sei }}, n\right)=I_{\text {sei }} / I_{\text {sc }} \cos \theta_{z}(n) \text {; }
$$

Here, $\cos \theta_{z}(n)$ is computed by:

$$
\cos \theta_{z}(n)=\cos \phi \cos \delta_{s} \cos \omega_{s}+\sin \phi \sin \delta_{s},
$$

where $\phi$ is the local latitude, $\delta_{s}$ is the current declination of the Sun, and $\omega_{s}$ is the hour angle.

Although there is an accepted value of $I_{\mathrm{sc}}=1360.8 \pm 0.5 \mathrm{Wm}^{-2}$ reported by Kopp G \& Lean JL (2011), this study does not account for experimental measurements of extraterrestrial solar irradiance at location for estimating the $I_{\text {sei }} / I_{\text {sc }}$ ratio. Therefore, fractional extraterrestrial irradiation changes are computed by (Duffie \& Beckman 2013):

$$
I_{\mathrm{sei}} / I_{\mathrm{sc}}=1+0.033 \cos 360^{\circ} \mathrm{n} / 365 \text {, }
$$

where $n$ is the day of the year.

Fig. 5 describes the behavior of $G\left(I_{\text {sei }}, n\right)$ for Leticia and Riohacha during the year. Leticia shows larger fractional changes at the beginning and the end of the year in contrast with Riohacha, which has more significant changes at the middle of the year.

It must be noted that $G\left(I_{\text {sei }}, n\right)$ depends upon the Earth's rotation, which is related to the zenith solar angle, and the Earth-Sun distance (Earth's translation around the Sun) by means of the extraterrestrial solar irradiance at location. Overall, $G\left(I_{\text {sei }}, n\right)$ sets in seasonal changes into the adaptive model.

The form factor $F(m, Y Y-T)$

From the fractional changes in solar radiation and seasonal patterns, the adaptive model describes an empirical function, $F(m, Y Y$ ) (depending on the month $m$ and the related year $Y Y$ ), that accounts for all unknown physical interaction processes between total column ozone and ultraviolet solar radiation, and daily discontinuities of TCO observations entangled in data: 


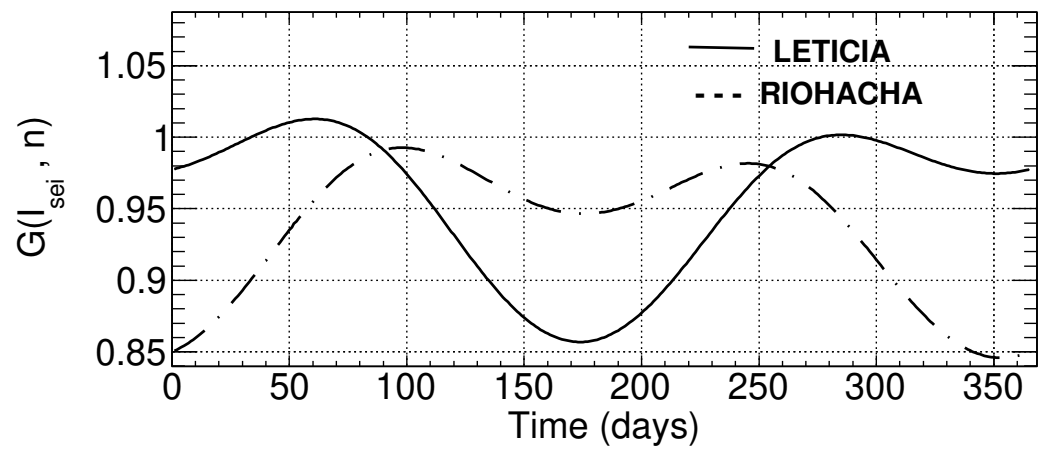

Figure 5. $G\left(I_{\text {sei }}, n\right)$ : Fractional extraterrestrial solar irradiance changes as a function of the day $n$ of the year, for Leticia and Riohacha.

$$
F(m, Y Y)=G\left[I_{\text {sei }}(m)\right] \frac{A_{\mathrm{m}}}{A_{\mathrm{YY}}},
$$

where TCO monthly averages, $A_{\mathrm{m}}$, are evaluated for a specific year $Y Y$, with a corresponding TCO yearly average $A_{\mathrm{YY}}$.

The fractional changes in the monthly TCO averages with respect to the yearly TCO average, $A_{\mathrm{m}} / A_{\mathrm{YY}}$, are modulated by monthly averages of $G\left[I_{\text {sei }}(m)\right]$. Fig. 6 and Fig. 7 illustrate dimensionless $F(m, Y Y)$ form factors for 39-years of Leticia's and Riohacha's historical data.

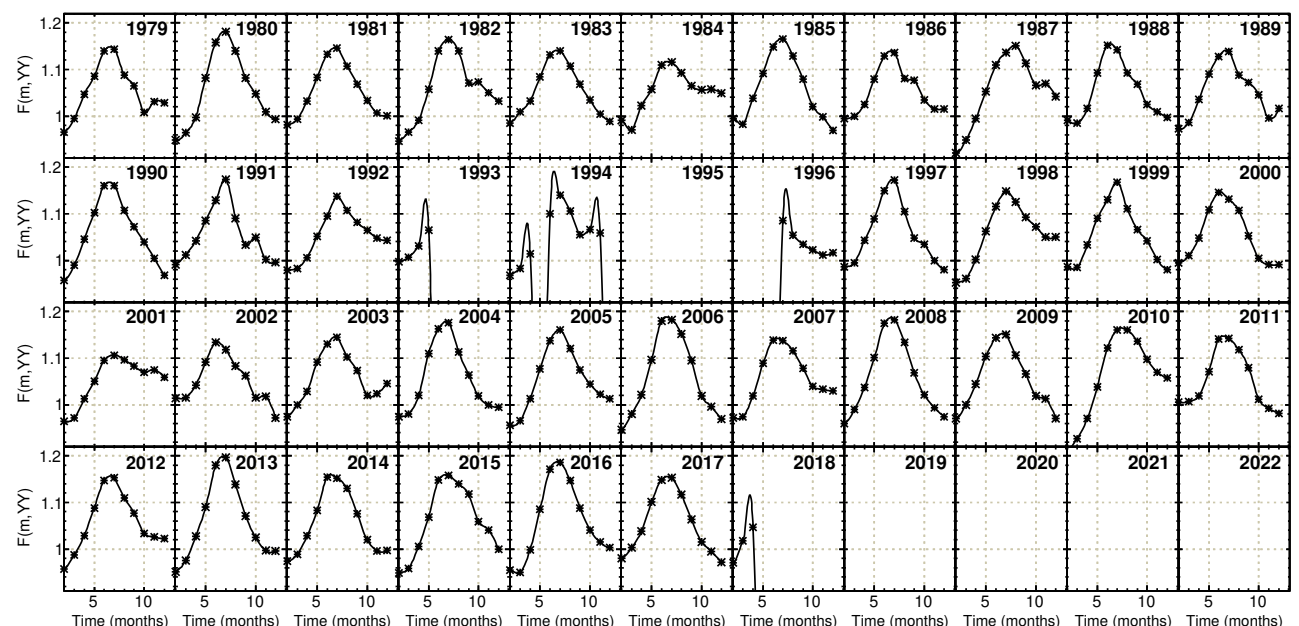

Figure 6. Dimensionless $F(m, Y Y)$ function for 39-years of historical data at Leticia's location. 


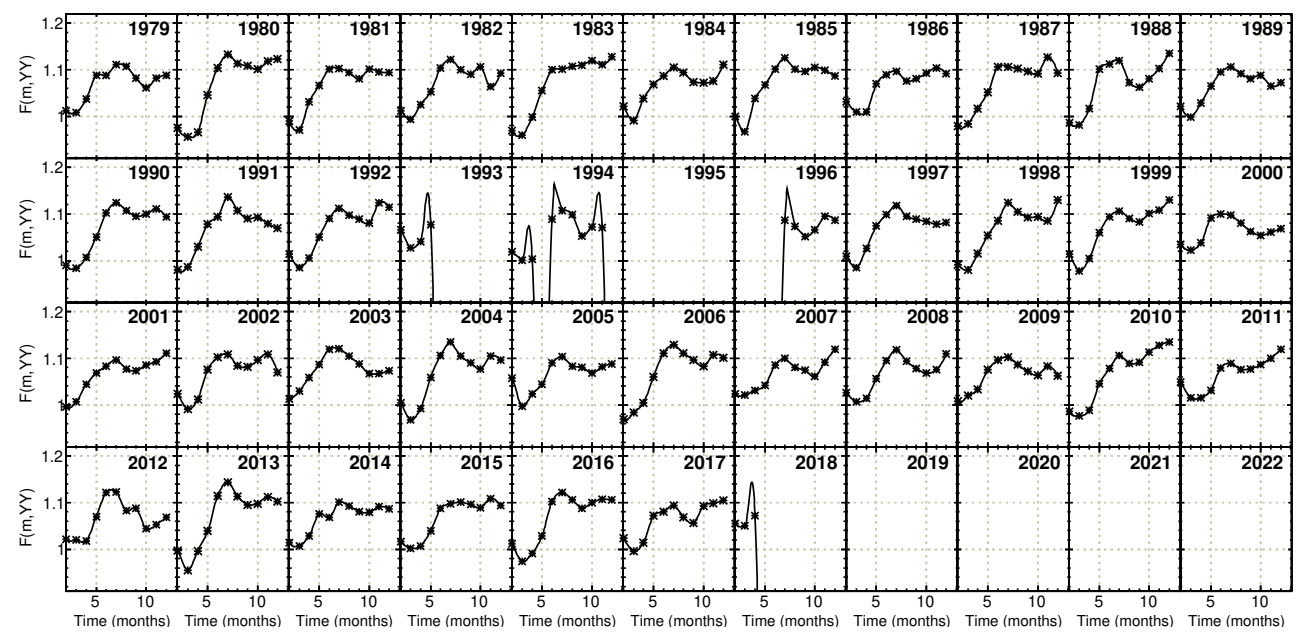

Figure 7. Dimensionless $F(m, Y Y)$ function for 39-years of historical data at Riohacha's location.

Results and discussion: TCO adaptive model predictions for Leticia and Riohacha

With the building blocks described above, the adaptive model $O_{3}(n, m, Y Y, T)$ given by Eq. (1), which is constantly fed by current TCO satellite measurements and $S_{n}$ data, can predict ozone behavior up to 11 years (from current data). Nonetheless, predictions for 11 years from now can be improved by adding daily current data. Fig. 8 and Fig. 9 show daily TCO predictions for Leticia and Riohacha.

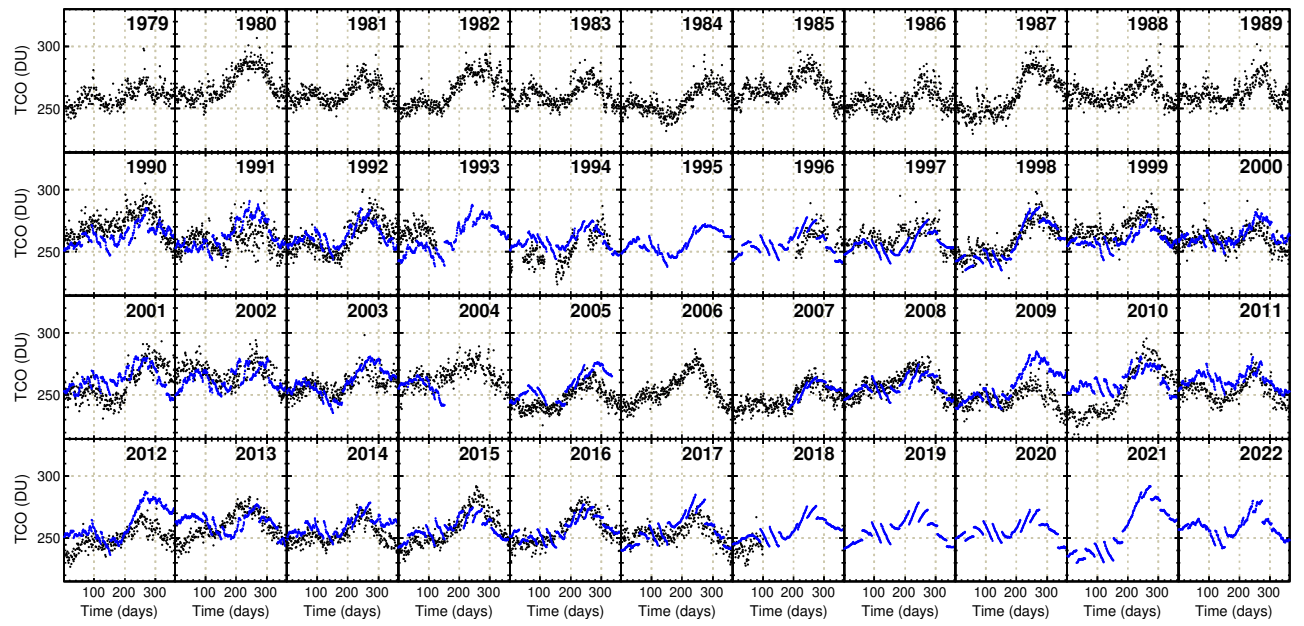

Figure 8. Comparative analysis between daily TCO satellite and predicted data for Leticia. The figure has 11 panels arranged horizontally because of the sunspot cycle period, $T=11$ years; this allows related years to be compared. 


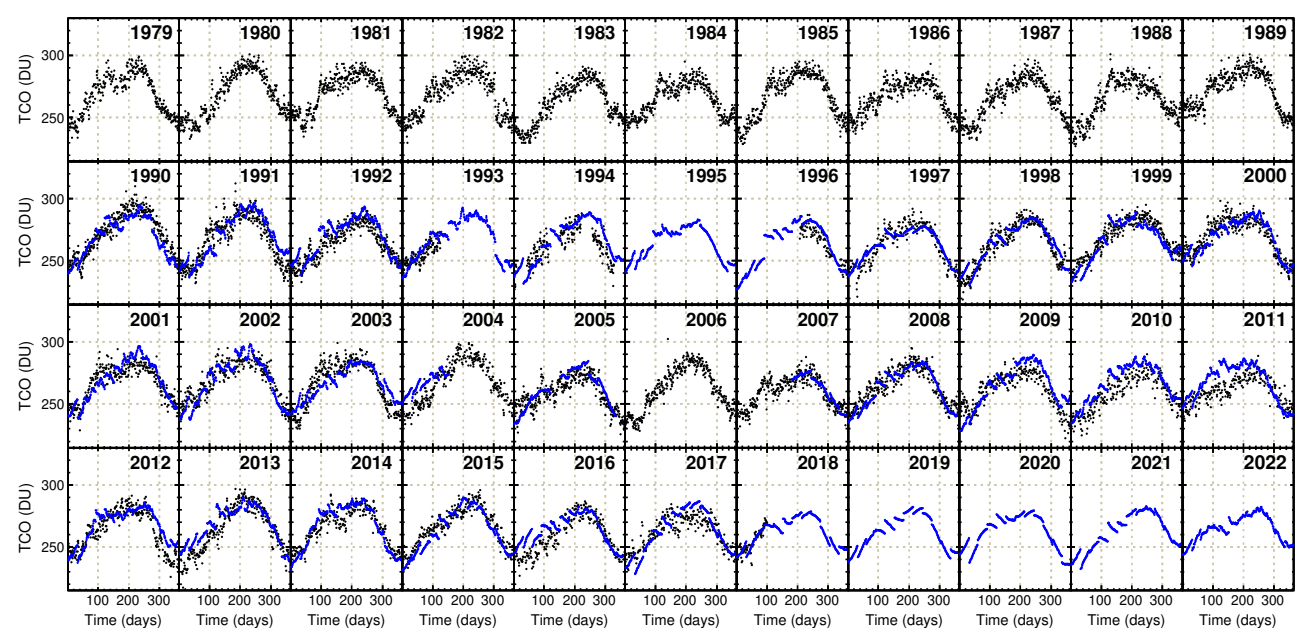

Figure 9. Comparative analysis between daily TCO satellite and predicted data for Riohacha. The figure has 11 panels arranged horizontally because of the sunspot cycle period, $T=11$ years; this allows related years to be compared.

Since smoothed values of sunspot number depend on daily observations, as shown in Fig. 3, the variations associated with these sunspot average values can be modeled as a function of the day.

As stated above, and from the fact that the satellite values of the ozone layer are related to the sunspot number (see Fig. 4), the model presented here suggests that the variability of daily ozone values are directly related to the daily sunspot number observations, which is periodically repeated, on average, every $T=11$ years.

Consequently, the corrections made by the form factor to predict ozone layer of a specific day in the future take into account the values of the form factor of the day, corresponding, on average, to the previous 11 years. This is why, for a specific year $Y Y$, the adaptive model uses the profile's form factor of the previous $T$ years, that is to say $F(m, Y Y-T)$.

As depicted in Fig. 8-9, adaptive model predicted data for 1990, 1992, 1993, 1994 and 1996 fit very accurately, day-by-day, with the observed satellite data; even though, available satellite data for 1993, 1994 and 1996 were scarce. From 1997 through 2018 , the adaptive model showed a considerable uniformity with respect to satellite data for the two locations.

In order to validate the model's adaptive predictions, daily-based relative errors of the observed satellite data were computed as shown in Fig. 10 and Fig. 11. 


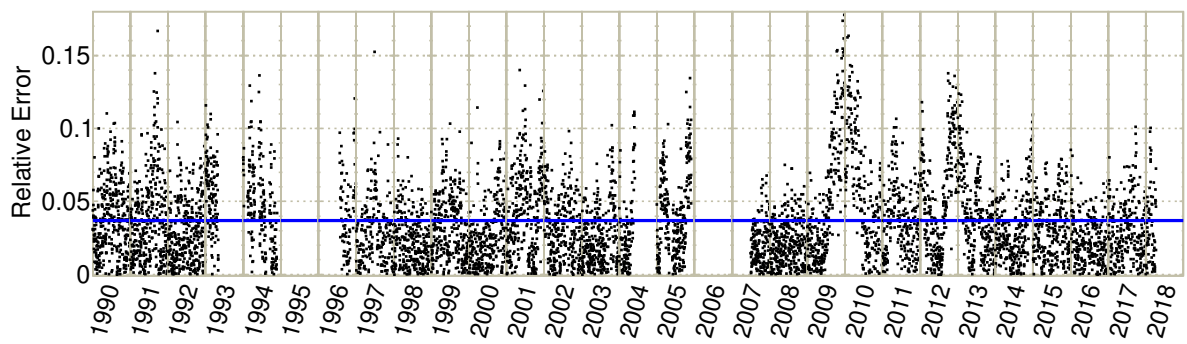

Figure 10. Relative error between satellite and predicted TCO data for Leticia.

On average, yearly percentage errors between the $\mathrm{O}_{3}(n, m, Y Y, T)$ adaptive model and the experimental satellite data range between $2.1 \%$ to $5.8 \%$, and $1.6 \%$ to $4.8 \%$, for Leticia and Riohacha, respectively; for the entire two samples, Leticia presents a $3.7 \%$ and Riohacha $2.8 \%$. This provides a reliable consistency in predicting experimental data by having, at least, 11 years of data or the corresponding sunspot cycle period.

Although there is no data for 1995 to compare with the 2006 predicted data, the reliable values of percentage errors allow the adaptive model to reconstruct any missing data from 1990 to 2018.

\section{Conclusions}

This study finds a linear relationship between sunspot number and TCO satellite observations for Riohacha and Leticia, consistent with the results for the city of Bogotá, where a direct relationship was found as well.

Extended adaptive model predictions of TCO for Leticia and Riohacha agree with TCO satellite data within a comparative yearly average errors up to $5.8 \%$ and $4.8 \%$, and, whole-sample average errors of $3.7 \%$ and $2.8 \%$, respectively.

Despite different latitudes the adaptive model makes significant daily predictions of TCO from 1990 to 2018. Adding to this, adaptive model predictions of TCO for the city of Bogotá in the Andes mountains (González-Navarrete \& Salamanca 2018) seem to be transparent to the altitude. Bogota rises high to an altitude of 2600 masl (meters above sea level) while Leticia and Riohacha lie very close to the sea level.

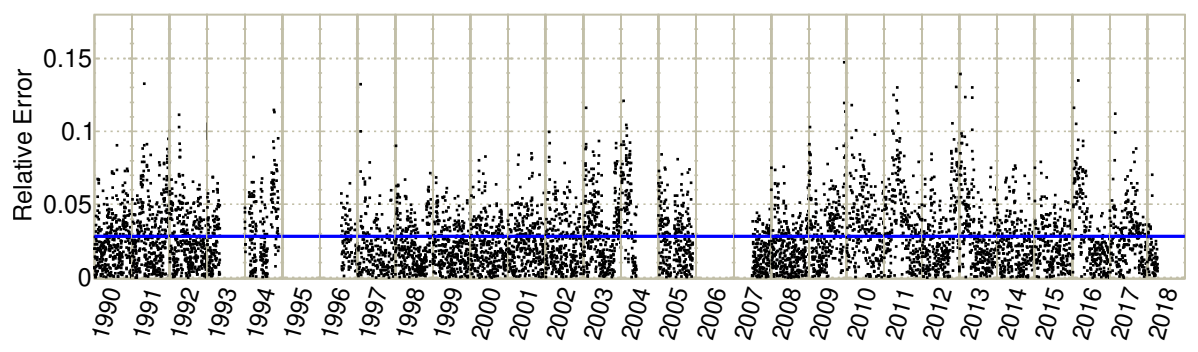

Figure 11. Relative error between satellite and predicted TCO data for Riohacha. 
Further studies from other locations outside of the ITCZ can use the $\mathrm{O}_{3}(n, m, Y Y, T)$ adaptive model as a starting point to predict total column ozone.

\section{Conflict of interest}

The authors declare that there are no conflicts of interest.

\section{References}

Angell JK. On the relation between atmospheric ozone and sunspot number. Journal of Climate, 2(11), 1404-1416, 1989.

Duffie JA, Beckman WA. Solar engineering of thermal processes. Wiley, New York, USA, 936 pp, 2013.

González-Navarrete JC, Salamanca J, Pinzón-Verano IM. Ozone layer adaptive model from direct relationship between solar activity and total column ozone for the tropical equator-AndesColombian region. Atmosfera, 31:2, 155-164, 2018.

doi: 10.20937/ATM.2018.31.02.04

Haigh JD, Winning AR, Toumi R, Harder JW. An influence of solar spectral variations on radiative forcing of climate. Nature, 467(7316), 696-699, 2010.

doi: $10.1038 /$ nature09426

Hathaway DH. The solar cycle. Living Review In Solar Physics, 12:4, 2015.

doi: 10.12942/lrsp-2010-1

Keating GM, Lake LR, Nicholson JY, Natarajan M. Global ozone long-term trends from satellite measurements and the response to solar activity variations. Journal of Geophysical Research: Oceans, 86(C10), 9873-9880, 1981.

Kopp G, Lean JL. A new, lower value of total solar irradiance: Evidence and climate significance. Geophysical Research Letters, 38, L01706, 2011.

doi: 10.1029/2010GL045777

Kuttippurath J, Nair PJ. The signs of Antarctic ozone hole recovery. Scientific reports, 7, 585, 2017.

doi: 10.1038/s41598-017-00722-7 
Labitzke K, Van Loon H. Total ozone and the 11-yr sunspot cycle. Journal of Atmospheric and Solar-Terrestrial Physics, 59(1), 9-19, 1997. doi: 10.1016/S1364-6826(96)00005-3

McPeters R. Space-based measurements of ozone and air quality. Ozone, Multimission ozone measurements. $N A S A$.

Retrieved from https://ozoneaq.gsfc.nasa.gov/data/ozone/ (last accessed on March 26, 2018)

Miyagawa K, Petropavlovskikh I, Evans RD, Long C, Wild J, Manney GL, Daffer WH. Long-term changes in the upper stratospheric ozone at Syowa, Antarctica. Atmospheric Chemistry and Physics, 14(8), 3945-3968, 2014.

doi: 10.5194/acp-14-3945-2014

Randel WJ,Wu F.Astratospheric ozone profile data set for 19792005: Variability, trends, and comparisons with column ozone data. Journal of Geophysical Research: Atmospheres, 112(D6), 2007.

doi: 10.1029/2006JD007339

Roscoe HK, Haigh JD. Influences of ozone depletion, the solar cycle and theQBO on the Southern Annular Mode. Quarterly Journal of theRoyal Meteorological Society, 133(628), 1855-1864, 2007. doi: $10.1002 /$ qj.153

Selvaraj RS, Gopinath T, Jayalakshmi K. Statistical relationship between Surface ozone and solar activity in a tropical rural coastal site, India. Indian Journal of Science and Technology, 3(7), 793-795, 2010 .

SILSO. World data center for the production, preservation and dissemination of the International sunspot number. Sunspot Index and Long-Term Solar Observations. Royal Observatory of Belgium, Brussels

Retrieved from

http://www.sidc.be/silso/ (last accessed on March 26, 2018)

Soukharev BE, Hood LL. Solar cycle variation of stratospheric ozone: Multiple regression analysis of long-term satellite data sets and comparisons with models. Journal of Geophysical Research: Atmospheres, 111(D20), 2006.

doi: 10.1029/2006JD007107 
Stolarski RS, Frith SM. Search for evidence of trend slow-down in the long-term TOMS/SBUV total ozone data record: the importance of instrument drift uncertainty. Atmospheric Chemistry and Physics, 6(12), 4057-4065, 2006.

doi: 10.5194/acp-6-4057-2006

Wellemeyer CG, Bhartia PK, Taylor SL, Qin W, Ahn C. Version 8 Total Ozone Mapping Spectrometer (TOMS) Algorithm. Proceedings of the XX Quadrennial Ozone Symposium, Vol. 1. No. 8, 2004.

Willett HC. The relationship of total atmospheric ozone to the sunspot cycle. Journal of Geophysical Research, 67(2), 661-670, 1962. doi: 10.1029/JZ067i002p00661

Zerefos C. Factors influencing the transmission of solar ultraviolet irradiance through the Earth's atmosphere. In Solar Ultraviolet Radiation, (pp. 133-141). Springer, Berlin, Heidelberg, 1997.

doi: 10.1007/978-3-662-03375-3_9 


\section{Predicciones de modelos adaptativos de columna total de ozono diaria en la Zona de Confluencia Inter-Tropical del Amazonas}

Resumen: El objetivo de este documento es ampliar el alcance de un reciente modelo adaptativo para hacer predicciones sobre tendencias de la columna total de ozono (CTO) sobre la Zona de Confluencia Inter-Tropical Amazónica (ZCIT). El modelo adaptativo hace predicciones diarias de CTO sobre la región ecuatorial-tropical de los Andes, basándose en patrones estacionales y el ciclo solar. Este estudio utiliza observaciones diarias del ciclo del número de manchas solares, suministradas por el Centro Mundial de Datos para la producción, preservación y diseminación del número de manchas solares internacional (Observatorio Real de Bélgica), y datos satelitales de columna total de ozono recolectados por NASA (enero 1979 a abril de 2018) para dos lugares geográficos en Colombia: uno dentro y el otro adyacente a la ZCIT. El acuerdo entre las predicciones diarias de la columna total hechas por el modelo adaptativo y las observaciones satelitales es excelente. Se repotan errores relativos promedio diarios alrededor de $3.7 \%$ y $2.8 \%$ para ambos lugares.

Palabras clave: zona de confluencia inter-tropical; radiación solar; número de manchas solares; columna total de ozono. 


\section{Prediçóes de modelos adaptativos da coluna total de ozônio diária na Zona de Confluência Inter-Tropical da Amazonia}

Resumo: AO objetivo deste documento é expandir o escopo de um modelo adaptativo recente para fazer predições sobre as tendências do coluna total de ozônio (CTO) na Zona de Confluência Inter-Tropical da Amazônia (ZCIT). O modelo adaptativo faz predições diárias da coluna total de ozônio sobre a região equatorial-tropical dos Andes, com base em padrões sazonais e no ciclo solar. Este estudo usa observações diárias do ciclo do número de manchas solares, fornecido pelo Centro Mundial de Dados para a produção, preservação e divulgação do número de manchas solares internacional (Observatório Real da Bélgica), e dados de satélite da coluna total de ozônio estratosférico colectados pela NASA (janeiro de 1979 a abril de 2018), para duas localizações geográficas na Colômbia: uma dentro e outra adjacente à ZCIT. A concordância entre as predições diárias da coluna total feitas pelo modelo adaptativo e as observações dos satélites é excelente. Neste documento, erros relativos médios diários em torno de $3.7 \%$ e $2.8 \%$ são relatados para ambos os locais.

Palavras-chave: zona de confluência inter-tropical; radiação solar; número de manchas solares; coluna total de ozono.

\section{Julio-César González-Navarrete}

Physicist, Master in Science-Physics (Universidad Nacional de Colombia). Retired Full-Professor of Universidad Nacional de Colombia, Department of Physics.

\section{Julian Salamanca}

Graduated in Physics, (Universidad Distrital Francisco José de Caldas). Master in Science-Physics (Universidad de los Andes, Bogotá-Colombia). PhD in Applied Physics, (Idaho State University and Thomas Jefferson Laboratory, USA). Currently Associate Professor at Universidad Distrital Francisco José de Caldas. 